\title{
Indigenous Self-Determination and the Legitimacy of Sovereign States
}

\author{
Paul Keal \\ Department of International Relations, Research School of Pacific and Asian Studies, Australian \\ National University, Canberra, Australian Capital Territory 0200, Australia. \\ E-mail: paul.keal@anu.edu.au
}

Self-determination is the cardinal right sought by Indigenous peoples and in practice it may require states to accept divisible sovereignty. For most states, selfdetermination is framed by decolonization and is applicable to Indigenous peoples only in limited senses of self-government within state structures. Self-determination, however, is enshrined in key human rights documents and by denying Indigenous peoples the right to it, they jeopardize the legitimacy of the human rights regime, and the legitimacy of the United Nations as a source of progressive international law. They also widen the rift between international and world society raising important questions for the legitimacy of the sovereignty system. International Politics (2007) 44, 287-305. doi:10.1057/palgrave.ip.8800189

Keywords: Indigenous peoples; legitimacy; recolonization; self-determination; sovereignty

\section{Introduction}

Sovereignty and self-determination are distinct but intertwined principles of central importance to the normative framework of international politics. The principle of self-determination is fundamental to statehood and the right to it is written into the key documents of the international human rights regime. It is an ethical component of the states system and it 'informs and complements' state sovereignty as a principle of international law (Brownlie, 1966, 483). In spite of or perhaps because of their centrality, self-determination and sovereignty are inherently unstable concepts. From one time to another there is no agreement over the exact content and scope of the two principles and states have difficulty dealing with this. Concerning self-determination, there is argument about whether it is a legal, moral or political principle, and an important question has been 'who has the right to determine what' (Shaw, 1986, 162). In conventional understandings, the right to self-determination has been represented as the right to an independent state, implying that it leads to sovereignty. Debate about sovereignty includes issues such as whether it has been diminished by globalization and whether or not it is divisible. The 
majority of states have been unable to satisfactorily resolve the selfdetermination claims of peoples within their borders, which are typically perceived as challenges to state sovereignty and the belief that sovereignty is indivisible.

The self-determination claims made by Indigenous peoples do not presently constitute an immediate crisis of political legitimacy for either the institution of the state or the governments exercising authority within states that have Indigenous populations. Self-determination is paramount among the rights sought by Indigenous peoples but most of them do not interpret this either as a right to statehood or sovereignty. They see it instead as meaning the ability to control their own cultural and economic destinies within existing state structures. This article, however, contends that failure to more fully recognize Indigenous rights and concerns could lead to increasing numbers of Indigenous peoples changing their interpretation of what sovereignty means. Failure to address Indigenous concerns now may lead to them adopting a more categorical conception of self-determination as sovereignty, conventionally understood.

In relation to crises of legitimacy the denial of their claims is, in the first place, a crisis for Indigenous peoples themselves. In the longer term, it has the potential to also become a crisis of legitimacy for the sovereign state because of Indigenous peoples, both within states and as part of an international movement, questioning and challenging the sovereignty exercised over them by governments. For Indigenous peoples denied the fundamental right of selfdetermination the nature of state sovereignty itself is problematic. Thwarting or over-riding their claims could, in the long run, result in Indigenous peoples deciding not to accept the legitimacy of the sovereign states in which they are located. In the language used by Christian Reus-Smit, legitimacy depends on social recognition freely given by a group, which constitutes the social constituency necessary to legitimate the state and the institutions through which sovereignty is exercised. If a sufficient number of Indigenous peoples in a particular state were to withdraw their recognition of the sovereignty vested in that state on their behalf, it could become a crisis for both the state as a unit of political organization and its government. It could in this way become a crisis not only for particular governments but when combined with other sub-state groups challenging the authority of other states, a crisis also for the institution of sovereignty on which the states system is founded. Regardless of this it can be argued that the denial of self-determination already is an international crisis of legitimacy for the human rights regime, which has the principle written into it.

In other words and to once again use Reus-Smit's framework, comprehensive legitimacy requires the social constituency of legitimation to be coextensive with the realm of political action of the institution or political actor in which 
legitimacy is vested. As Indigenous peoples have been relatively powerless and marginalized in the process of state formation, governments have been able to afford, politically, to be unconcerned with whether Indigenous peoples are part of their social constituency of legitimation. For Indigenous peoples this has resulted in the inability to achieve some of the goals they regard as important, including recognition of the right to self-determination. At the same time as not being essential to the social constituency of legitimation of the state to which they belong Indigenous peoples are very much part of its realm of political action. The government and courts of a state with Indigenous populations has, by virtue of the sovereignty invested in it, the ability to, among other things, grant or deny land rights, negotiate or refuse to negotiate the reconciliation of historic injustices, make decisions about how Indigenous people within their borders will live, all of which can vitally affect the reproduction of Indigenous culture and identity. In doing these things it might or might not be concerned with whether it satisfies the goals and claims of its Indigenous peoples. They are unlikely to be an essential part of its social constituency of legitimation. This mismatch between the two realms becomes a crisis for individual states when a sufficient number of Indigenous peoples and their non-Indigenous supporters both withdraw their electoral support from governments and question the legitimacy of the sovereign state as a unit of political organization. It becomes an international crisis when the international movement of Indigenous peoples and its non-Indigenous supporters have sufficient political influence to unite both the world society of non-state actors and the international society of states in questioning, to the point that it cannot be ignored, the legitimacy of states that continue to deny recognition of the right of Indigenous peoples to self-determination.

The article is in four sections, of which the first considers the definition of Indigenous peoples and the nature of their involvement, as actors, in world politics. The second focuses on self-determination and argues that Indigenous claims to it are critical to unresolved political business left over from colonization and the question of whether or not sovereignty is divisible. At the centre of the dispute between Indigenous and non-Indigenous peoples is a 'collision of sovereignties', which undermines the legitimacy of sovereign states containing Indigenous peoples. As well as this, by observing existing international legal instruments in the breech, and by failing to adopt the Draft United Nations Declaration on the Rights of Indigenous Peoples, states both weaken the force of international law and unsettle important norms that do not have the status of law. The third brief section discusses sovereignty as essential to achieving self-determination and the contrary assessment that it is inevitably a justification for disempowering Indigenous peoples. The final section suggests three routes to resolving the tension between the legitimacy of the sovereign state and rights claimed by Indigenous peoples: reconciliation, 
recognition of multiple and overlapping sovereignties, and adoption of the Draft Declaration including Article 3, which proclaims the right to selfdetermination.

\section{Who is Indigenous?}

The definition of Indigenous peoples is disputed. In spite of the Draft Declaration on the Rights of Indigenous Peoples the United Nations has no official definition. The three main working definitions advanced under its auspices are those contained in the International Labour Organization's Convention No. 169 (ILO 169), and in reports by UN rapporteurs José Martinéz Cobo and Erica Irene Daes (Hughes, 2003, 15). Of these the most comprehensive and widely cited is Cobo's, stated in his 1986 Report for the UN Sub-Commission on the Prevention of Discrimination and Protection of Minorities:

Indigenous communities, peoples and nations are those which, having a historical continuity with pre-invasion and pre-colonial societies that developed on their territories, consider themselves distinct from other sectors of society now prevailing in territories or parts of them. They form at present non-dominant sectors of society and are determined to preserve, develop, and transmit to future generations of their ancestral territories, and their ethnic identity, the basis of their continued existence as peoples, in accordance with their cultural patterns, social institutions and legal systems (Cobo, 1986/7).

Ronald Niezen rightly comments that while this is 'comprehensive and durable ... it does not apply unfailingly to all situations in which people claim indigenous status and protections' (Niezen, 2003, 20).

Colonial settlement is generally interpreted as European settlement. Consequently several Asian states that did not experience substantial European settlement have argued "that the concept of "indigenous peoples" is so integral to the common experience of European colonial settlement as to be fundamentally inapplicable to' them (Kingsbury, 1999, 340). Historical continuity is similarly problematic. While there are many places where the inhabitants of lands subjected to colonization clearly were the original inhabitants, in other places they had themselves been settlers. They were not the original inhabitants. Defining Indigenous peoples in terms of who came first is one reason why India and China insist that the concept does not apply within their borders. India argues that 'centuries of migration, absorption, and differentiation [have made it] ... impossible to say who came first' (Kingsbury, 1999, 352). Not only that, Kingsbury makes the important point that when 
"indigenousness of "sons of the soil" becomes the basis of legitimation for a politically or militarily dominant group [as in Fiji and Malaysia], restraints on abuses of power can be difficult to maintain' (Kingsbury, 1999, 353).

Having recognized these limitations, the focus of this article is the descendants of peoples who were subjected to colonization, primarily, but not necessarily, by Europeans. It is the common experiences resulting from colonization that have caused a very diverse range of peoples to cohere into an international movement seeking rights. Professor Mick Dodson, formerly Aboriginal and Torres Strait Islander Social Justice Commissioner, recalls the first time he attended a session of the UN Working Group on Indigenous Populations. Surrounded by people from around the world, he found they shared the same stories and sufferings.

We were all part of a world community of Indigenous peoples spanning the planet; experiencing the same problems and struggling against the same alienation, marginalisation and sense of powerlessness. We had gathered there united by our shared frustration with the dominant systems in our own countries and their consistent failure to deliver justice. We were all looking for, and demanding, justice from a higher authority (cited in Niezen, 2003, 47).

It is this experience of sharing a common sense of frustration, of having been marginalized politically, legally and materially that has brought diverse Indigenous peoples from around the world together in a global movement (Niezen, 2003, 13). The sense of Indigenous identity which animates this international Indigenous movement is grounded in 'the logic of conquest and colonialism' and similarities in the treatment of Indigenous peoples by settler states. Of particular importance has been the loss of subsistence. Indigenous peoples claim a special relationship with their lands, territories and resources, over which they have prior rights. According to Erica Irene Daes ' $t]$ he reconciliation of the legitimate interests of States with the prior rights of Indigenous peoples to their natural resources has been recognized by many as a critical and necessary step for the advancement of the rights of indigenous peoples'. She argues 'that meaningful political and economic self-determination of indigenous peoples will never be possible without indigenous peoples' having the legal authority to exercise control over their lands and territories' (www.unpo.org/news_detail.php?arg $=02 \&$ par $=3367$ ).

In summary, Indigenous identity, what it is to be an Indigenous person, is best understood in terms of the common experiences arising from colonization, which have brought diverse Indigenous peoples together in a global movement of resistance seeking recognition of the rights they claim and in particular the right to self-determination. The loss of subsistence and sovereign rights visited upon Indigenous peoples as a result of conquest and colonization continues to 
the present, with many Indigenous peoples seeing themselves as existing in varying degrees of internal colonization. Their prior sovereignty has been overridden by the dominant settler societies that progressively dispossessed them. Self-determination claims are, as well as anything else, a call to end colonial relationships between Indigenous and non-Indigenous peoples. The next section turns to self-determination as the key right sought by Indigenous peoples and why the claim to it is, with few exceptions, rejected by sovereign states.

\section{Self-Determination}

There are two points essential to the argument that follows. Firstly, the right to self-determination is written into the international human rights regime. The so-called 'Common Article 1' of both the International Covenant on Civil and Political Rights (ICCPR), and the International Covenant on Economic, Social and Cultural Rights (ICESCR) proclaim the right of all 'peoples', under international law, to self-determination. 'All peoples have the right to selfdetermination. By virtue of that right they freely determine their political status and freely pursue their economic, social and cultural development.' Of particular importance is that the 'Common Article 1' right of self-determination is understood to include the right of secession and full independence (www.unpo.org/news_detail.php?arg $=02 \&$ par $=3527$ ).

Neither of the Covenants was framed with Indigenous peoples in mind and whether the term 'peoples' includes them is disputed. Regardless of this, inclusion of self-determination in the human rights regime raises the question of whether denying Indigenous peoples the right to self-determination is tantamount to denying them a fundamental human right. A further question is that of the extent to which the right of Indigenous peoples to selfdetermination has already been accepted. Ambiguities surrounding the extent to which human rights provide for Indigenous peoples are one reason why the global Indigenous movement has sought a distinct set of Indigenous rights. The United Nations Draft Declaration on the Rights of Indigenous Peoples, which has yet to be adopted, proclaims the specific right of Indigenous peoples to selfdetermination in Article 3. As well as this it stipulates that: 'By virtue of that right they freely determine their political status and freely pursue their economic, social and cultural development.'

Secondly, in relation to Indigenous peoples the meaning given to selfdetermination in international law has been determined by decolonization. For colonized peoples self-determination was about having the freedom to decide for themselves whether they wanted either to be independent or to associate with some state other than the one that had colonized and exercised 
sovereignty over them. Precluded from this process was the freedom to revise the territorial boundaries of former colonies. Besides that, a number of former colonies had long since gained independence and were not part of the post-war decolonization. In either case, Indigenous peoples did not benefit from decolonization and remained encased in states that continued to deny them rights. They remained subject to internal colonization.

Self-determination is a potent idea. The right to secession and full independence, mentioned above, threatens the integrity of territorial sovereign states. Inherent in the principle of self-determination, as it has developed, is a contradiction between the rights of states and the rights of minorities within states to dismember or challenge the state in the name of another competing norm of self-determination' (Simpson, 1996, 259-260). Selfdetermination has as its basis the existence of groups, which define themselves as nations. Historically it has been represented as a call for the unity of nation and state in which the one is an expression of the other. It is a principle of state creation but equally it is the basis of claims for breaking states into smaller units.

Precisely because self-determination claims 'could lead to a very different world map', self-determination has been regarded as the 'most problematic topic in indigenous peoples' rights' and as one that 'strikes at the legitimacy of settler regimes'. It is thus argued that at the heart of debate in Geneva over the Draft Declaration has been 'an ideological battle pitting the legitimacy of hundreds of ancient nations of indigenous peoples against the asserted legitimacy of Westphalian states' (Morris, 2003, 125). States worry about whether self-determination for Indigenous peoples 'can be reconciled with [their] concern ... to maintain their territorial integrity and with the concern of the international community not to risk unlimited fragmentation of existing states' (Kingsbury, 1992, 485).

During the 11th session of the United Nations Inter-sessional Working Group on the Draft Declaration on the Rights of Indigenous Peoples (WGDD), held in Geneva December 5-16, 2005, debate over the meaning of self-determination for Indigenous peoples continued to be a major sticking point. While many countries 'agreed to recognize a genuine right of selfdetermination for indigenous peoples,' others continued to fear that Indigenous nations 'may try to secede and form independent countries.' More precisely, their fear is that the right to self-determination will lead to the right to secede. States — including the United States, Indonesia, China, New Zealand and Australia - all have concerns about whether recognition of the right to self-determination would 'not disrupt their territorial integrity' (www.unpo.org/news_detail.php?arg=02\&par=3380).

Australia, New Zealand and the United States agreed 'that secession and independence are not the intended outcome of Article 3'. They nevertheless 
jointly proposed the creation of 'a new understanding of self-determination as a right that is to be exercised within an existing nation-state and is not intended to impact in any way on the political unity or territorial integrity of any States.' These three states argued that Article 3 could not be simply a repetition of Common Article 1, but had instead to explain 'exactly what is meant by the term self-determination that relates to Indigenous Peoples' (www.unpo.org/ news_detail.php?arg=02\&par $=3367$ ).

Their statement made it abundantly clear that this would require 'a meaningful Article 3 definition of self-determination that describes the rights of indigenous peoples residing within an existing nation-state, in a clear and understandable manner' (www.unpo.org/news_detail.php?arg=02\&par = 3367). The common position adopted by these three states is 'that reference must be made to preserving the territorial integrity and political unity of States in the operative parts of the draft Declaration.' The delegations from these countries insisted that the adoption of many articles in the draft 'depends upon the inclusion of an Article 45 referring explicitly to the territorial integrity of existing states' (www.unpo.org/news_detail.php?arg=02\&par=3527). In response many groups of Indigenous peoples remain adamant that Article 3 and Article 31, which provides for autonomy and self-government, must remain unqualified (www.unpo.org/news_detail.php?arg=02\&par=3527).

As long as key states such as the United States, Australia and New Zealand link Article 3 to the possibility of secession and independence, progress toward adoption of the Draft Declaration will remain limited. The reluctance of many states to move beyond the legal meaning given to self-determination in the era of decolonization makes them unwilling to accept the autonomy within states sought by Indigenous peoples as proper instances of self-determination. States worry that adoption of Article 3 of the Draft Declaration on the Rights of Indigenous Peoples would eventually mean 'separate legal systems covering all manner of things from taxation and gambling to criminal law and marriage relationships' (Brennan, 1995, 151).

James Anaya argues that limiting self-determination to peoples in colonial situations 'denies its relevance to all segments of humanity' and overlooks its connection, as a principle, with human rights (Anaya, 1996, 77). It cannot, he argues, now be separated from the expression it has been given in a variety of human rights instruments, the significance of which is illustrated by the situation of Indigenous peoples in, among other places, Australia and Canada. Self-determination, understood as decolonization resulting in the establishment of new states, has not been a possibility for these peoples. Responding to claims to self-determination by Indigenous peoples in these and other states by saying that they are not in a colonial situation, and hence not entitled to make such claims, amounts to denying a fundamental right stipulated in a number of human rights instruments. 
In making this case, Anaya distinguishes between remedial and substantive aspects of self-determination. Remedial measures are those which correct colonization as a deviation from self-determination. The substantive aspect is defined by recognition of 'a standard of governmental legitimacy within the human rights framework'. The substance of self-determination is expressed, he argues, in 'shared opinion and behaviour about the minimum conditions for the constitution and functioning of legitimate government', meant to benefit all 'peoples' (1996, 81). Anaya argues that human rights instruments articulate norms about non-discrimination, cultural integrity, lands and resources, social welfare and development, and self-government. Each of these is of fundamental importance to indigenous peoples and the norms that have been established about them 'elaborate on the requirements of self-determination' (1996, 112).

The international human rights regime already incorporates rights sought by Indigenous peoples but a major hurdle for Indigenous rights has been that they are rights claimed by groups, which in some cases constitute nations. For states, this reinforces the idea that Indigenous claims to self-determination might result in fragmentation. As well as this, group rights have tended to be rejected as ones that discriminate against non-Indigenous citizens within state boundaries. Self-determination is clearly a right sought by groups and so the denial of group rights is linked to the denial of self-determination. States continue to stop short of accepting that Indigenous groups are 'peoples' comprehended in international law as entitled to self-determination. In spite of this there is now a growing body of resolutions by various $\mathrm{UN}$ and regional human rights institutions that have affirmed the collective rights of Indigenous peoples.

These include ILO 169, which 'recognizes indigenous peoples as distinct groups with certain rights as such in a way that places those rights and conceptions of indigenous identity apart from attributes of statehood'; decisions of the Inter-American Court upholding the collective rights of Indigenous communities; and the UN Human Rights Committee invoking 'the right of self-determination ... affirmed in general terms in Article 1 of the Covenant ... [when] defining the scope of state responsibility toward indigenous people' (Anaya, 2005, 309). As the number of such precedents grow, the more Indigenous peoples are likely to question the legitimacy of states that deny or block the rights claimed by Indigenous peoples. Particularly is this the case if it is the right to self-determination.

For the bulk of Indigenous peoples, legal and political obstacles mean it would be not easy, and perhaps impossible, to separate themselves from the nation-states in which they are located. Writing in 1995 about Australia, Frank Brennan SJ argued that self-determination really means 'entitlement of indigenous groups to make decisions about their economic, social and cultural 
development without unwarranted interference by the State' (Brennan, 1995, 148-149). At the risk of unduly labouring the point, self-determination for Indigenous peoples has been interpreted in ways that fall short of challenging the sovereign state (Morris, 2003). Understood in this way, self-determination for Indigenous peoples is to be achieved within the framework of existing sovereign states.

\section{Sovereignty}

This is challenged by the argument that without sovereignty in their own right, Indigenous peoples will be unable to fully realize their political and cultural rights. In other words, they need 'indigenous sovereignty', which would restore to them authorship of their own distinct cultural identities. According to Joanne Barker, sovereignty 'emanates from the unique identity and culture of peoples and is therefore an inherent and inalienable right of peoples to the qualities customarily associated with nations' (Barker, 2005, 3). Sovereignty is linked to the distinctive identities different peoples possess and which are at the core of 'nations'. In contrast, conventional discourses of sovereignty are 'unable to capture fully the indigenous meanings, perspectives, and identities about law, governance, and culture, and thus over time it impacts how those epistemologies and perspectives are represented and understood' (Barker, 2005 , 19). The meaning given to 'sovereignty' in discourses of Indigenous sovereignty is thus clearly different from the one it has in international relations. States and Indigenous peoples disagree about the meaning and scope of 'sovereignty'. Like self-determination, Indigenous sovereignty does not entail secession and statehood; it could be established and exercised within existing state structures. It does nevertheless imply that sovereignty is divisible, and for states that believe this would inexorably lead to the fragmentation of territory and authority, it is unimaginable, if not unthinkable.

A more radical position is taken by those who reject altogether the language of sovereignty as alien to Indigenous peoples. Canadian First Nation scholars Dale Turner and Taiaiake Alfred regard European notions of self-determination and sovereignty as tools of oppression. Turner describes Western European discourses of rights and sovereignty as 'the most devastating landscapes that have been forced upon Aboriginal peoples'. 'These intellectual traditions have created discourses on property, ethics, political sovereignty, and justice that have subjugated, distorted, and marginalized Aboriginal ways of thinking' (Turner, 2001, 325). He asserts that, in the history of Indigenous contact with settler societies, very little, if any, attention has been given to Aboriginal conceptions of sovereignty. 'Aboriginal peoples have had to use Western European discourses of rights and sovereignty to explain their place in 
the world' $(2001,327)$. They have, in other words, been denied the capacity to talk about this in their own terms, which would include a very different view of sovereignty.

For Alfred 'sovereignty is an exclusionary concept rooted in an adversarial and coercive notion of power' (Alfred, 1999, 59). It is inappropriate both as a model for Indigenous governance and as a 'political objective for indigenous peoples' (Alfred, 2005b, 38). In his view "AAboriginal rights" and "tribal sovereignty" are in fact the benefits accrued by indigenous peoples who have agreed to abandon autonomy to enter the state's legal and political framework' (2005b, 39). "Acceptance of "Aboriginal rights" in the context of state sovereignty represents the culmination of white society's efforts to assimilate indigenous peoples' (Alfred, 1999, 59). Rather than giving Indigenous people control over their lives, the quest for sovereignty might simply result in placing structures of domination into the hands of Indigenous administrators. 'The state', Alfred continues, "'relegates indigenous peoples" rights to the past, and constrains the development of their societies by allowing only those activities that support its own necessary illusion: that indigenous peoples do not present a serious challenge to its legitimacy'. Basing claims to legitimacy 'on the rule of law is hypocritical and anti-historic' (Alfred, 1999, 59).

In this way Alfred challenges the concept of sovereignty as a concept able to comprehend Indigenous concerns. His critique is one that contests the legitimacy of the sovereign states for Indigenous peoples. Were it to become widely adopted by the international Indigenous movement, it would have the potential to unsettle the principle and practice of sovereignty and widen the gap between international and world society. Regardless of this, it is clear that the collective rights claimed by Indigenous peoples do bring the legitimacy of sovereign states into contention.

\section{How Might the Rights of Indigenous Peoples and the Legitimacy of the Sovereign State be Resolved?}

The issues that trouble Indigenous peoples most, that are most disruptive of their relations with the states in which they live, and over which they are most likely to seek international redress, are ones that have their origin in colonization and its legacy of internal colonialism. Margaret Moore identifies three kinds of arguments that 'question the legitimacy of the state in relation to governing indigenous peoples: lack of consent, unjust dispossession, and unjust treatment or historical injustices' (Moore, 2004, 2). Colonizers typically took the land of Indigenous peoples without their consent and in important cases denied them any prior sovereignty. A complaint shared by Indigenous peoples is that they did not consent to their land being taken or to the establishment of 
settler nations that followed. As a consequence of the loss of land and the failure to recognize their prior sovereignty, Indigenous peoples lost access to and control over the resources vital to the reproduction of their cultures. The key to resolving these issues and rights of Indigenous peoples, and the legitimacy of the sovereign state generally, is international recognition of the right of Indigenous peoples to self-determination in international and constitutional law.

As approaches to resolving the tension between Indigenous rights and the legitimacy of the sovereign state, what follows considers: first, reconciliation and, as routes to it, 'practical recolonization' and treaties; second, multiple and overlapping sovereignties; and finally, adoption of the Draft Declaration with Article 3 unaltered, in conjunction with adherence to UN human rights standards.

\section{Reconciliation}

Reconciliation is 'a process that brings people together to enjoy a more peaceful, mutually acceptable, and settled state of affairs' (Borrows, 2005, 617). In relation to Indigenous peoples, reconciliation would mean resolving the problems that exist between them and non-Indigenous others. In Canada and Australia, to take just two examples, the consequences of a number of perceived past and continuing injustices continue to divide Indigenous and non-Indigenous peoples. These include the forced removal of children from their families, loss of ancestral lands and the destruction of cultures. In both states this has resulted in movements calling for the respective governments to apologize for past actions. Helping people come to grips with the past and move on alongside each other is a major aim of truth and reconciliation commissions, such as the one that was presided over by Archbishop Desmond Tutu in South Africa.

Dealing with past dispossession and injustice involves dealing with issues of compensation and restitution, which might require positive discrimination measures. This, however, together with calls to recognize distinct rights for Indigenous peoples because of their first-nation status, has been resisted by non-Indigenous peoples. In the example of Australia, special treatment for Aboriginal Australians and other people regarded as 'different' was opposed by supporters of the short lived One Nation party. For this party and its leader, Pauline Hanson, 'the recognition of Indigenous difference amounts to a kind of discrimination' (Borrows, 2005, 622). This line of thinking has been defended by the current Federal government, which rejects treating Indigenous Australians differently, favouring instead a policy of 'practical reconciliation'. The three objectives of this are: improved living standards for all Australians; not apportioning blame or guilt for past wrongs; and, 'mutual acceptance of 
the importance of working together and appreciating differences in a way that does not prevent people from sharing their futures together' (Borrows, 2005, 619). In a searching and innovative critique of this approach, John Borrows argues a case for differential treatment. He distinguishes between 'formal' and 'substantive' equality. Formal equality calls for 'similarity of treatment'. Substantive equality is, in contrast, the notion that differential treatment is a necessary mechanism for achieving equal standards.

In support of this, Borrows finds grounds for differential treatment in international legal principle. He cites in particular, the argument put by Judge Tanaka in the South West Africa case. Tanaka took the position 'that the principle of non-discrimination requires both the equal treatment of equals and the consideration of difference in assessing the need for differential treatment' (Borrows, 2005, 622). Borrows suggests that this position appears to be also accepted in the International Convention on the Elimination of All Forms of Racial Discrimination. With reference to the particular example of Indigenous Australians, he argues that:

The problems faced by Indigenous Australians are often referable to negative treatment of their differences from non-Indigenous Australians, and therefore we must affirmatively address these differences. Colonisation has affected Indigenous peoples in a unique way, creating a different set of problems for them than for others in society. These differences are unlikely to go away by treating them the same as others are treated in all circumstances. In fact, many problems can be exacerbated by applying solutions without regard for these differences (Borrows, 2005, 623).

As a means to dealing with them, Borrows calls not for practical reconciliation but practical recolonization. He asks why Indigenous peoples should 'be the only group in society not to receive the benefits of colonization?' His response is that '[i]f equality of opportunity is to be the means by which Indigenous peoples improve their lives, Indigenous peoples should have an equal opportunity to participate with others in the colonization of Australia' (2005, 630). Each of the benefits that would be conferred by practical recolonization listed by Borrows would rectify a harm or injustice that has resulted from colonization. It is unlikely that Borrows believes practical recolonization is ever likely to be translated into public policy. Regardless of this, the very idea is a brilliant discursive ploy that challenges the logic of arguments for equal and undifferentiated treatment. At the same time, it reveals the limitations of reconciliation.

Despite these limitations, reconciliation is an important means to legitimating the state in the eyes of at least some, if not the majority of Indigenous people. For others, however, reconciliation is simply doomed to failure as it results only in reinforcing the subjugation of Indigenous people to the 
sovereignty of settler states. Alfred more stridently argues that reconciliation results in giving Indigenous peoples 'a place inside Settler society with no requirement for settlers to forego any of their ill-gotten gains personally or collectively'. Reconciliation is only ever limited and 'does not address fundamental problems - logically and morally, there is no escaping that the problems of colonialism experienced by Onkwehonwe [original people] are a direct result of the theft of their lands and cannot be addressed in any other way than through its return to them' (Alfred, 2005a, 154). In essence, reconciliation cannot deliver the cardinal right of self-determination, not to mention sovereignty. Ipso facto it can only result in a partial resolution of Indigenous rights and the legitimacy of the sovereign state.

For there to be reconciliation, and for the legitimacy of the sovereign state to be accepted by Indigenous peoples, there must be a resolution of political relations. One means to achieving this is through a 'treaty'; but not of the kind comprehended by international law. It need not be a written document but based instead on mutual understanding about appropriate behaviour based on the acceptance of difference. Writing about the specific case of Canada, Michael Asch explains that '[t]he concept of "Treaty" ... in indigenous thought, proposes to seek resolution of political relations through entering into an enduring nation-to-nation relationship based on the principle that the parties respect each other's autonomy and establish a common project that involves sharing among them. The intent of the parties', he continues, "is to foster "peace and friendship" in perpetuity and therefore always includes ways to resolve difficulties and improve relations' (Asch, 2004, 8).

One way of arriving at a 'treaty' of this kind would be by reaching a clear mutual understanding of the kind of law and institutions modern societies need if they are to allow for 'forms of self-government appropriate to the recognition of cultural diversity' (Tully, 1995, 5). With this in mind, James Tully has written about constitutions, which recognize cultural diversity by accommodating it. A constitution is, for him, a 'form of activity, an intercultural dialogue in which the culturally diverse citizens of contemporary societies negotiate agreements on their forms of association over time in accordance with the three conventions of mutual recognition, consent and cultural continuity' (Tully, 1995, 30). Mutual recognition refers to the requirement that a just form of constitution must 'give recognition to the legitimate demands of diverse cultures in a manner that renders everyone their due' (Tully, 1995, 6). Consent is the principle that a constitution should be an expression of popular sovereignty; and cultural continuity requires 'respect for the continuity of cultures of self-rule.' For Tully the form of government most likely to deliver this would be a multinational democracy based on dialogue and a dialogic ethic that respects difference. 
In European political thought, the state has typically been conceptualized as the container of a single community or nation, which is implicit in the idea of the nation-state. The presence of Indigenous and other minority peoples within states points to the state as a container of not one, but several, communities. In Canada, in particular, First Nations insist that negotiation with the dominant settler society must be on a nation-to-nation basis, signifying in part, 'a special relationship with the state'. First Nations claim that the relationship between them and the state is properly one between nations, which implies that each nation possesses some measure of sovereignty. The idea of states being multi-national leads in turn to what Naeem Inayatullah and David Blaney refer to as 'multiple and overlapping sovereignties'. Their argument is that the Peace of Westphalia resulted in the belief that difference in international relations had been dealt with by making states the containers of it. Within states, difference was subjected to the Empire of Uniformity, understood as a language of constitutionalism 'designed to exclude or assimilate cultural diversity and justify uniformity' (Tully, 1995, 58). As a means to dealing with difference within states and re-imagining sovereignty in a way "that works against the "empire of uniformity", they propose Benedict Anderson's concept of 'multiple and overlapping sovereignties', which, they say, is suggestive of a 'patchwork of identities and authorities' (Inayatullah and Blaney, 2004, 212).

In their analysis, sovereignty is a 'property right of rulers' $(2004,188)$. They argue that the idea of sovereignty is used to 'divide space and bundle its varied meanings into discrete, homogenous, and absolute cultural units. Thus, sovereignty is often treated as an answer to the problem of adjudicating competing claims to land or territory' (2004, 190-191). If, however, there is to be any hope of resolving the conflicts created by difference within states a more imaginative approach is needed. Inayatullah and Blaney cite Beirut, Sarajevo, and Jerusalem as "cities that have been torn ... by mutually excluding claims made by opposing social groups. Each of the competing parties claims the right to inhabit the same land, use it as an economic resource, and derive their identities and history from that use and habitation' (2004, 204). In common with this, Indigenous claims also involve inhabiting and sharing the same land. As a solution to mutually excluding claims, Inayatullah and Blaney suggest when it is ' $[\mathrm{n}] \mathrm{o}$ longer treated as a homogeneous substance, sovereignty might be divided and distributed to create complex jurisdictional arrangements involving settlements that must be continuously renegotiated and as well as uncertainties that must be navigated by dialogue' $(2004,213)$.

At the heart of this is the question of whether sovereignty is divisible. The tendency has been to regard it as indivisible, but increasingly it is becoming an 
open or permissive concept. Commenting on the nature of contemporary sovereignty, the eminent Professor of Public Law, Yash Ghai wrote that

Special forms of representation, autonomy - general or asymmetrical have become part of constitutions. State sovereignty gets diffused, shared, parceled, so that increasingly full state sovereignty can be exercised only through the co-operation of different institutions and groups. The sum total of powers exercised by state organs at different levels is sovereignty but it has become greatly transformed in responding to pressures from above and compulsions from below. It is unlikely that a state could survive today if its sovereignty was not sufficiently flexible to accommodate these pressures and compulsions (Ghai, 2003).

Without radical reconceptualization, self-determination within state structures falls short of what Indigenous peoples want. It needs to rest on Indigenous sovereignty. If this is not going to be disruptive and resisted by states, state sovereignty must be thought as divisible, which, if Professor Ghai is right, it already and probably always has been. If it is accepted as divisible, the arguments against adoption of the Draft Declaration become less persuasive.

\section{Adopt the Draft Declaration and Uphold Established International Norms}

To the extent that there is an international crisis of legitimacy for the sovereign state with regard to Indigenous peoples, it is one that has resulted from the failure of states, so far, to adopt the UN Draft Declaration on Indigenous Rights and in so doing recognize the right of Indigenous peoples to selfdetermination as part of a distinct set of rights. Instead of this, many states have resisted extending the rights of Indigenous peoples. Consequently, Indigenous representatives to the WGDD have complained that states do not act in accord with UN standards on the rights of Indigenous peoples, and are not held accountable for not doing so.

A joint submission, tabled by 35 Indigenous organizations at the 11 th Session of the WGDD, argued that the failure to uphold standards and improve the standard-setting process is especially evident in relation to such core Indigenous issues as the right of self-determination and rights to land, territories and resources' (www.unpo.org/news_detail.php?arg=02\&par=3285). It continued by arguing that contrary to a General Assembly Resolution adopted in 2000, which enjoined 'all human rights bodies within the United Nations system', to act 'in strict compliance with the purposes and principles of the Charter', the WGDD had consistently failed to do so. Instead the Chair of the WGDD had, over a five-year period, 'rejected all requests by Indigenous peoples and organizations to introduce criteria that would ensure that its 
mandate is carried out in a manner that fully upholds the Purposes and Principles of the UN Charter. It had as well ignored criteria related to the progressive development of international law (www.unpo.org/news_detail. php?arg = 02\&par $=3285$ ).

At the heart of these arguments is the concern Indigenous peoples have about self-determination as a fundamental human right to which Indigenous peoples everywhere are entitled. Two important implications of this are first, that by denying the right to self-determination to Indigenous peoples, states diminish their legitimacy in the estimation of Indigenous peoples and their supporters and potentially of international society. The way out of this is to accept that Indigenous peoples do have that right and act upon it. Second, it can be argued that, to the extent that they ignore or shape human rights law and norms to their own ends, states contribute to an international crisis over the status of international law, and the legitimacy of global governance and the core concepts of self-determination and sovereignty. Only by defending and upholding accepted human rights principles can the tension between Indigenous rights and the legitimacy of the sovereign state be resolved. Further, because human rights do not fully provide the group rights needed for the reproduction of Indigenous cultures, they need to be augmented by the distinct set of Indigenous rights set out in the Draft Declaration.

\section{Conclusion}

For Indigenous peoples, the right to self-determination in both international and constitutional law is pivotal for both distinct Indigenous rights and the reproduction of Indigenous cultures around the globe. Indigenous peoples in a number of states have had, or continue to have, self-determination that has taken the form of limited self-government within state structures. From the perspective of many Indigenous peoples, the problem with this has been that it does not adequately deal with important issues left over from colonization, which have yet to be resolved. Foremost among these are the prior sovereignty of Indigenous peoples and the right to exercise authority over land and resources. One of the factors which brings Indigenous peoples together in an international movement is their concern over the legitimacy of state sovereignty. The movement is for this reason a movement of resistance, which opposes complete assimilation and seeks to safeguard Indigenous identities. '[T]rue conquest', Alfred argues, 'becomes inevitable when the Settler's claims to legitimacy are accepted and normalized by Onkwehonwe. Legitimation (acceptance and support for colonial institutions) is the fundamental battlefield' (Alfred, 2005a, 56). In other words, if the state succeeds in legitimating itself through Indigenous peoples finally accepting its sovereign authority, the battle for Indigenous rights will be decisively lost. 
A critical turning point has been reached in the progress of the UN Draft Declaration on the Rights of Indigenous Peoples; and by extension the outlook for self-determination and Indigenous sovereignty. The Declaration has now been adopted by the UN Commission on Human Rights and will at last be put to the General Assembly for adoption. If it is rejected because of Article 3, that will undermine the legitimacy of the United Nations as an organization able to play a positive role in creating and upholding progressive norms in the interest of world society rather than particular states. It will also have an important bearing on established human rights norms.

There is presently a mismatch between the social constituency of Indigenous rights and the political realm in which action must be taken if they are to be fully legitimated. Recalibration between the two will have primarily to take place within states through policies of 'national' reconciliation. As Ian Clark rightly notes in his conclusion, this "can ... be facilitated through international institutions, and other international forms of socialization'. International society has the capacity to act as a standard bearer in this regard, but it also has a rich history of disempowering Indigenous peoples. Without admitting more flexible notions of sovereignty and self-determination, including the divisibility of sovereignty, any fundamental recalibration will be difficult to achieve. Regardless of Indigenous peoples being relatively weak actors in the international system of sovereign states, failure to satisfactorily resolve their claims to self-determination could have eventual repercussions for the system as a whole. It has the potential to further sap legitimacy from the two intertwined principles that currently constitute the basic norms of international politics.

\section{References}

Alfred, T. (1999) Peace, Power, Righteousness: An Indigenous Manifesto, Ontario: Oxford University Press.

Alfred, T. (2005a) Wasáse: Indigenous Pathways of Freedom and Action, Toronto: Broadview Press.

Alfred, T. (2005b) 'Sovereignty', in J. Baker (ed.) Sovereignty Matters: Locations of Contestation and Possibility in Indigenous Struggles for Self-Determination, Lincoln and London: University of Nebraska Press.

Anaya, S.J. (1996) Indigenous Peoples in International Law, New York: Oxford University Press.

Anaya, S.J. (2005) 'Review Article', American Journal of International Law 99(1): 306-310.

Asch, M. (2004) 'Sovereignty, Self-Determination and Treaties: Resolving Political Relations between First Nations and Canada', unpublished paper.

Barker, J. (2005) 'For Whom Sovereignty Matters', in J. Baker (ed.) Sovereignty Matters: Locations of Contestation and Possibility in Indigenous Struggles for Self-Determination, Lincoln and London: University of Nebraska Press.

Borrows, J. (2005) 'Practical Recolonisation?' University of New South Wales Law Journal 28(3): 614-645.

Brennan, F. (1995) One Land One Nation: Mabo-Towards 2001, St Lucia: University of Queensland Press. 
Brownlie, I. (1966) The Principles of Public International Law, Oxford: Oxford University Press.

Cobo, J.M. (1986/7) Study of the Problem against Indigenous Populations, vol. v, Conclusions, Proposals and Recommendations, UN Doc E/CN 4/Sub 2 1986/7, Add, 4 para 379.

Ghai, Y. (2003) 'Personal correspondence from Professor Yash Ghai to Mr Anthony J. Regan, December 3.

Hughes, L. (2003) The No-Nonsense Guide to Indigenous Peoples, London: Verso.

Inayatullah, N. and Blaney, D. (2004) International Relations and the Problem of Difference, New York and London: Routledge.

Kingsbury, B. (1992) 'Claims by Non-State Groups in International Law', Cornell International Law Journal 25(3): 481-513.

Kingsbury, B. (1999) 'The Applicability of the International Legal Concept of "Indigenous Peoples" in Asia', in J.R. Bauer and D.A Bell (eds.) The East Asia Challenge For Human Rights, Cambridge: Cambridge University Press.

Moore, M. (2004) 'Political Legitimacy and Indigenous Peoples', unpublished paper presented to the Demcon conference, University of Victoria, BC, October 2-3.

Morris, G.T. (2003) 'Vine Deloria, Jr., and the Development of a Decolonizing Critique of Indigenous Peoples and International Relations', in R.A Grounds, G.F Tinker and D.E. Wilkins (eds.) Native Voices: American Indian Identity and Resistance, Lawrence, Kansas: University Press of Kansas.

Niezen, R. (2003) The Origins of Indigenism: Human Rights and the Politics of Identity, Berkeley: University of California Press.

Shaw, M. (1986) International Law, 2nd edn, Cambridge: Grotius Publications.

Simpson, G.J. (1996) 'The Diffusion of Sovereignty: Self-Determination in the Post-Colonial Age', Stanford Journal of International Law 32(2): 255-286.

Tully, J. (1995) Strange Multiplicity: Constitutionalism in an Age of Diversity, Cambridge: Cambridge University Press.

Turner, D. (2001) 'Vision: Toward an Understanding of Aboriginal Sovereignty', in R. Beiner and W. Norman (eds.) Canadian Political Philosophy: Contemporary Reflections, Ontario: Oxford University Press. 